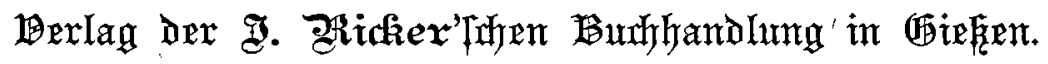

\title{
(berditid) tswi
}

Bbkkex., Siehe Stubien, Bießener, a. b. Beb. b. Befdjifte.

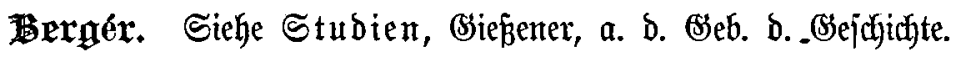

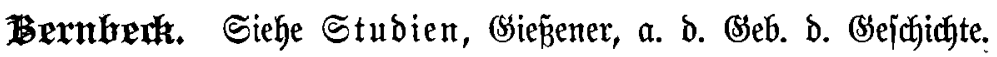

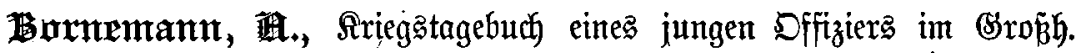

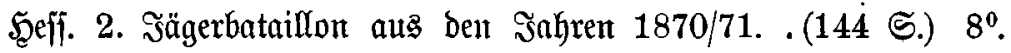
1895.

eleg. broch. M. $1.50 ;$ geb. $\mathfrak{M}$. 2.30

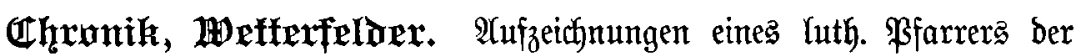

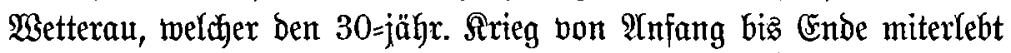
hat, herauggegeber, erflärt unb erläutert von Friebrich @isaf zu

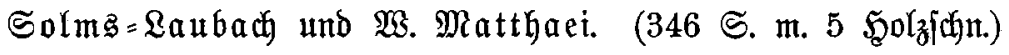
$8^{0} .1882$.

M. 8.-

Gähtgens, Panl, Die Beziehungen zwischen Brandenburg und Pommern unter Kurfürst Friedrich II. (1437) 1440-1470. (152 S.) $8^{\circ}$. 1890.

M. 2.60

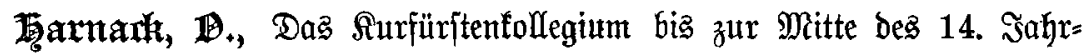

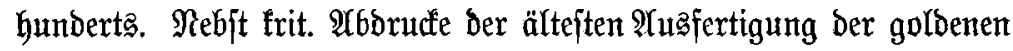

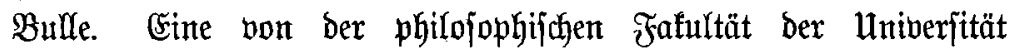

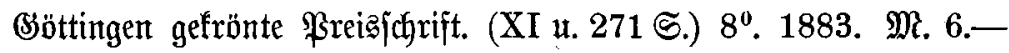

Höfner, M. J., Untersuchungen zur Geschichte des Kaisers L. Septimius Severus und seiner Dynastie. Bd. I. (VIII u. 328 S.) $8^{0} .1875$.

M. 6.60

Keutgen, F., Die Beziehungen der Hanse zu England im letzten Drittel des vierzehnten Jahrhunderts. (91 S.) $8^{0}$. 1890. M. 2.-

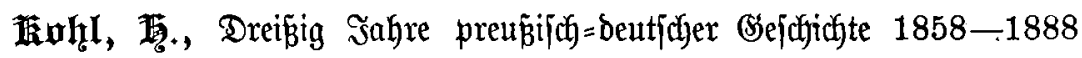

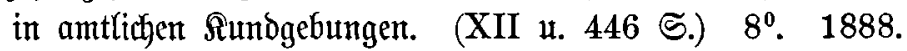

brocf. M. $4.50 ;$ gef. 2 ntbb. M. 5.75

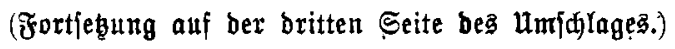




\section{LUDWIG III.}

\section{Kurfürst von der Pfalz}

\section{und das Reich}

\section{0-1427.}

Ein Beitrag

zor

deutschen Reichsgeschichte unter König Sigmund

von

\section{Wilhelm Eberhard}

Dr. phil.

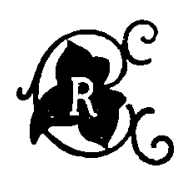

GIESSEN

J. Ricker'sche Buchhandlung 1896. 
Alle Rechte vorbehalten. 
Herrn

\section{Professor Dr. K. Höhlbaum \\ in}

Dankbarkeit und Verehrung

gewidmet. 
